\title{
Mitochondrial DNA in human identification: a review
}

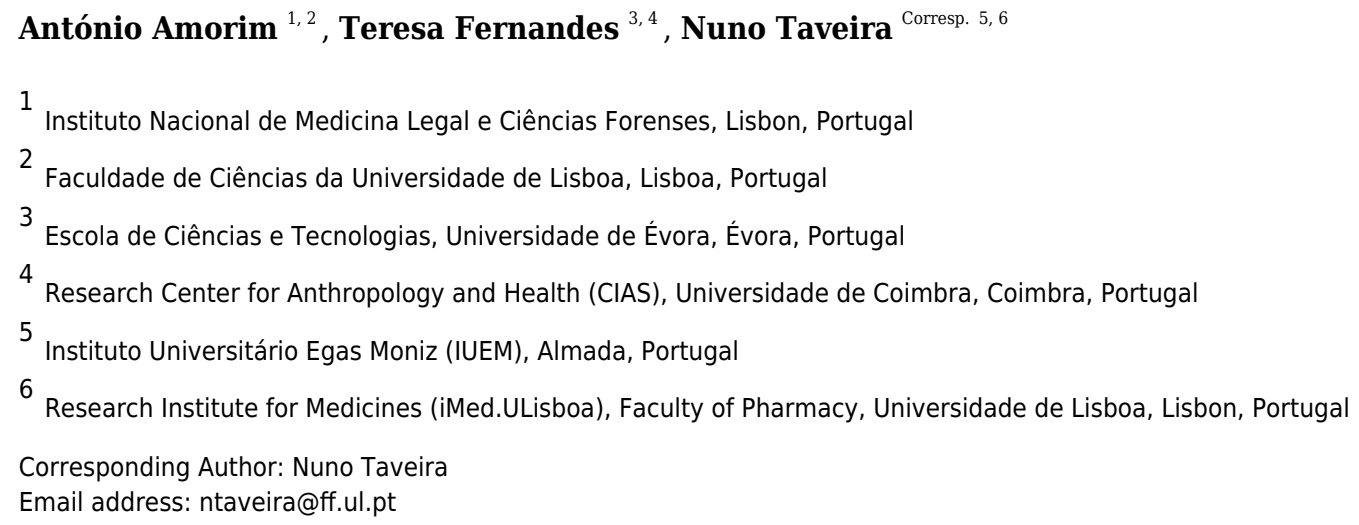

Mitochondrial DNA (mtDNA) presents several characteristics useful for forensic studies, especially related to the lack of recombination, to a high copy number, and to matrilineal inheritance. mtDNA typing based on sequences of the control region or full genomic sequences analysis is used to analyze a variety of forensic samples such as old bones, teeth and hair, as well as other biological samples where the DNA content is low.

Evaluation and reporting of the results requires careful consideration of biological issues as well as other issues such as nomenclature and reference population databases. In this work we review mitochondrial DNA profiling methods used for human identification and present their use in the main cases of humanidentification focusing on the most relevant issues for forensics. 


\section{Mitochondrial DNA in Human Identification: a review}

\section{Authors}

3 António Amorim ${ }^{1,2}$, Teresa Fernandes ${ }^{3,4}$, Nuno Taveira ${ }^{5,6^{*}}$

4

5 Affiliations

$6 \quad{ }^{1}$ Instituto Nacional de Medicina Legal e Ciências Forenses, Lisboa, Portugal

$7 \quad$ 2Faculdade de Ciências da Universidade de Lisboa, Lisboa, Portugal

$8{ }^{3}$ Escola de Ciências e Tecnologias, Universidade de Évora, Évora, Portugal

$9{ }^{4}$ Research Center for Anthropology and Health (CIAS), Universidade de Coimbra

10 5Instituto Universitário Egas Moniz (IUEM), Almada, Portugal

$11{ }^{6}$ Research Institute for Medicines (iMed.ULisboa), Faculty of Pharmacy, Universidade de

12 Lisboa, Portugal

13

$14 *$ Corresponding author:

15 Nuno Taveira

16 Research Institute for Medicines (iMed.ULisboa), Faculty of Pharmacy, Universidade de Lisboa,

17 Av. Prof. Gama Pinto, 1649-003 Lisbon, Portugal

18 ntaveira@ff.ul.pt 


\section{Abstract}

21 Mitochondrial DNA (mtDNA) presents several characteristics useful for forensic studies, 22 especially related to the lack of recombination, to a high copy number, and to matrilineal 23 inheritance. mtDNA typing based on sequences of the control region or full genomic sequences 24 analysis is used to analyze a variety of forensic samples such as old bones, teeth and hair, as well 25 as other biological samples where the DNA content is low. Evaluation and reporting of the 26 results requires careful consideration of biological issues as well as other issues such as 27 nomenclature and reference population databases. In this work we review mitochondrial DNA 28 profiling methods used for human identification and present their use in the main cases of human 29 identification focusing on the most relevant issues for forensics. 
30

31

32

\section{4}

\section{Introduction}

Human genetic identification for forensic purposes is achieved through the definition of genetic profiles. A genetic profile or the genetic fingerprint of an individual is the phenotypic description of a set of genomic loci that are specific to that individual. In accordance with international recommendations, particularly with recommendations of the European DNA Profiling Group (EDNAP), currently, only genetic profiles obtained from autosomal short tandem repeats (STR) should be used for genetic fingerprinting. However, in a considerable number of situations of human identification, autosomal DNA is highly degraded or isn't available at all. In these cases the study of mitochondrial DNA (mtDNA) for human identification can be the last appeal and by that reason has become routine (Budowle, Allard, Wilson, \& Chakraborty, 2003). Nevertheless, and despite the robustness of mtDNA in cases of exclusion or absence of identity between sequences, when the results are sequence identity, contrary to nuclear markers, they do not refer to an individual but to a group of individuals of the same maternal lineage.

\section{Survey methodology}

We systematically searched with PubMed Advanced Search Builder for papers Titles with the following combinations 1) mitochondrial DNA and biology, 2) mitochondrial DNA and guidelines, 3) mitochondrial DNA and nomenclature, 4) mitochondrial DNA and sequencing, 5) mitochondrial DNA and database, 6) mitochondrial DNA and data, 7) mitochondrial DNA and identification, 8) mitochondrial DNA and forensic. Papers nonrelated with human or animal mitochondrial DNA were excluded. Our search wasn't refined by publishing date, journal or impact factor of the journal, authors or authors affiliations. In addition, we used Guideline 
52 documents from the International Society for Forensic Genetics available at

53 https://www.isfg.org/

54

\section{Mitochondrial DNA biology and genetics}

56 Mitochondria are cellular organelles that contain an extrachromosomal genome, which is both

57 different and separate from the nuclear genome. The mitochondrial DNA (mtDNA) was first

58 identified and isolated by Margit Nass and Sylvan Nass in 1963, who studied some

59 mitochondrial fibers that according to their fixation, stabilization and staining behavior, appeared

60 to be DNA related (Nass \& Nass, 1963). However, the complete sequence of the first mtDNA

61 was only published and established as the mtDNA Cambridge Reference Sequence (CRS)

62 eighteen years later, in 1981 (Anderson et al., 1981).

63 Essentially, the mtDNA is a $5 \mathrm{~mm}$ histone-free circular double-stranded DNA molecule, with 64 around 16569 base-pairs and weighting $10^{7}$ Daltons (Taanman, 1999). mtDNA strands have 65 different densities due to different $\mathrm{G}+\mathrm{T}$ base composition. The heavy $(\mathrm{H})$ strand encodes more 66 information, with genes for two rRNAs (12S and 16S), twelve polypeptides and fourteen tRNAs, 67 while the light (L) strand encodes eight tRNAs and one polypeptide. All the 13 protein products 68 are part of the enzyme complexes that constitute the oxidative phosphorylation system. Other 69 characteristic features of the mtDNA are the intronless genes and the limited, or even absent, 70 intergenic sequences, except in one regulatory region.

71 The mitochondrial D-loop is a triple-stranded region found in the major non-coding region 72 (NCR) of many mitochondrial genomes, and is formed by stable incorporation of a third 680 73 bases DNA strand known as 7S DNA (Kefi-Ben Atig, Hsouna, Beraud-Colomb, \& Abdelhak, 74 2009). The origin of replication is located at the non-coding or D-loop region, a 1121 base pairs 
75 segment that is located between positions 16024 and 576, according to the CRS numeration

76 (Anderson et al., 1981) (Figure 1). The D-loop region, also comprehends two transcription

77 promotors, one for each strand. Nucleotide positions in the mtDNA genome are numbered

78 according to the convention presented by Anderson et al. (Anderson et al., 1981), which was

79 slightly modified by Andrews et al. (Andrews et al., 1999), determining the replacement of CRS

80 for rCRS (revised Cambridge Reference Sequence). More precisely, the numerical designation of

81 each base pair is initiated at an arbitrary position on the $\mathrm{H}$ strand, which continues thereafter and

82 around the molecule for approximately 16569 base pairs.

83 The apparent lack of mtDNA repair mechanisms and the low fidelity of the mtDNA polymerase

84 lead to a significant higher mutation rate in the mitochondrial genome, when compared to the

85 nuclear genome. For example, Sigurğardóttir and collaborators, estimated the mutation rate in

86 the human mtDNA control region to be $0.32 \times 10^{-6} /$ site/year (Sigurðardóttir, Helgason, Gulcher,

87 Stefansson, \& Donnelly, 2000) which compares to $0.5 \times 10^{-9} /$ site/year in the nuclear genome

88 (Scally, 2016). Most of the sequence variation between individuals is found in two specific

89 segments of the control region, namely in the hypervariable region 1 (HV1, positions 16024 to

9016365 ) and in the hypervariable region 2 (HV2, positions 73 to 340) (Greenberg, Newbold, \&

91 Sugino, 1983). A third hypervariable region (HV3, positions 438 to 574), with additional

92 polymorphic positions can be useful in the resolution of indistinguishable HV1/HV2 samples

93 (Lutz et al., 2000). The small size and relatively high inter-person variability of the HV regions

94 are very useful features for forensic testing purposes.

95 The mtDNA sequence defines the individual haplotype which is reported by the different base

96 pairs relative to the rCRS mtDNA sequence. The collection of similar haplotypes defined by the

97 combination of single nucleotide polymorphisms (SNPs) in mtDNA inherited from a common 
98 ancestor defines an haplogroup which was formed as a result of the sequential accumulation of 99 mutations through maternal lineage (Mitchell et al., 2015).

100 A mitochondrion contains 2 to 10 copies of mtDNA and each somatic cell can have up to 1000 101 mitochondria (Elson, Samuels, Turnbull, \& Chinnery, 2001; Wei et al., 2017). Hence, when the 102 amount of the extracted DNA is quite small or degraded, it is more likely that a DNA typing 103 result can be obtained by typing the mtDNA than by typing polymorphic regions that are found 104 in nuclear DNA.

105 Contrarily to the nuclear DNA, the mtDNA is exclusively maternally inherited, which justifies 106 the fact that, apart from mutation, mtDNA sequence of siblings and all maternal relatives is 107 identical (Case \& Wallace, 1981; Giles, Blanc, Cann, \& Wallace, 1980; Hutchison, Newbold, 108 Potter, \& Edgell, 1974). This specific characteristic can be very helpful in forensic cases, such as 109 in the analysis of the remains of a missing person, where the known maternal relatives can 110 provide some reference samples for a direct comparison to the mtDNA type. Due to the lack of 111 recombination, maternal relatives from several generations apart from the source of evidence (or 112 biological material) can be used for reference samples (Case \& Wallace, 1981; Giles et al., 1980; 113 Hutchison et al., 1974).

114 The haploid and monoclonal nature of the mtDNA in most individuals simplifies the process of 115 interpretation of the DNA sequencing results. Still, it is possible to find heteroplasmy at 116 occasional cases (Bendall, Macaulay, \& Sykes, 1997; Bendall \& Sykes, 1995; Comas, Paabo, \& 117 Bertranpetit, 1995; Gill et al., 1994; Ivanov et al., 1996; Wilson, Polanskey, Replogle, DiZinno, 118 \& Budowle, 1997). A person is considered as heteroplasmic if she/he carries more than one 119 detectable mtDNA type. There are two classes of heteroplasmy, related to length polymorphisms 120 and to point substitutions. Only the latter is important for forensic human identification. Most 
121 forensic laboratories worldwide do not report length polymorphisms and the guidelines on

122 human identification with mtDNA do not point them as mandatory information (W. Parson et al., 123 2014; Prinz et al., 2007). Furthermore, the information of length polymorphisms has no impact in 124 haplogroups' definition.

125 Heteroplasmy manifests itself in diverse ways (Stewart et al., 2001). An individual may show 126 more than one mtDNA type in a single tissue. An individual may be heteroplasmic in one tissue 127 sample and homoplasmic in another one. Finally, an individual may exhibit one mtDNA type in 128 one tissue and a different type in another tissue. Of the three possible scenarios, the last one is 129 the least likely to occur. When heteroplasmy is found in the mtDNA of an individual, it usually 130 differs at a single base, in HV1 or HV2.

131 Heteroplasmy was observed at position 16,169 of the mtDNA control region in the putative 132 remains of Tsar Nicholas II of Russia and his brother, the Grand Duke of Russia Georgij 133 Romanov (Gill et al., 1994; Ivanov et al., 1996). Comas et al. (Comas et al., 1995), in turn, 134 detected heteroplasmy at two distinct positions, 16, 293 and 16,311, in the mtDNA of an 135 anonymous donor's plucked hair. Wilson et al. (Wilson et al., 1997) found a family constituted 136 by a mother and two children carrying a heteroplasmic mtDNA at position 16,355 both in blood 137 and buccal swab samples.

138 The existence of heteroplasmic individuals and the limited knowledge about both the mechanism 139 and the rate of heteroplasmy can be issues raised in an attempt to exclude mtDNA evidence from 140 forensic investigations. Heteroplasmy at one nucleotide position is more frequently observed in 141 hair samples, mainly due to genetic drift and to bottlenecks which occur due to the hair follicle's 142 semiclonal nature (Budowle et al., 2003; Buffoli et al., 2013; Paus, 1998; Rogers, 2004). Hence, 143 if an evidentiary hair sample contains one of the two heteroplasmic lineages that are observed in 
144 a reference sample, or vice versa, then the interpretation of exclusion may be incorrect. In this

145 case, typing additional hairs may be required to solve the problem (Budowle et al., 2003).

146 As it was previously pointed out, it is accepted that the mitochondrial genome is maternally

147 inherited. Even though the sperm contains a few mitochondria in the neck and in the tail region,

148 the male mitochondrial genome is destroyed either during or shortly after the fertilization. More

149 precisely, sperm mitochondria disappear in the early embryogenesis, either by selective

150 destruction, inactivation or dilution (Cummins, Wakayama, \& Yanagimachi, 1997; H. Shitara et

151 al., 2000; Hiroshi Shitara, Hayashi, Takahama, Kaneda, \& Yonekawa, 1998; D. C. Wallace,

152 2007). Nonethless, in the last years some cases of biparental mtDNA inheritance have been

153 reported. In the most recent case, Luo and collaborators describe biparental mtDNA inheritance,

154 either directly or indirectly, in 17 members of three multigenerational families, with results

155 confirmed by 2 independent laboratories (Luo et al., 2018). Besides this report in humans, there

156 are also a few examples of paternal inheritance of the mitochondrial genome in animals

157 (Gyllensten, Wharton, Josefsson, \& Wilson, 1991), and by that reason and despite the limited

158 evidence for paternal inheritance of the mitochondrial genome in humans, the courtroom can be

159 tempted to use such possibility to depreciate the use mtDNA evidences.

160

\section{Mitochondrial DNA Nomenclature}

162 Considering that listing more than 600 bases in order to describe the results from a new HV1 and

163 HV2 sequence would be unpractical, an alternative approach was developed which essentially

164 identifies and reports the differences relative to the reference sequence rCRS (Anderson et al., 165 1981). 
166 Even though the process of naming mtDNA sequences seems simple and obvious, it is crucial to 167 properly consider the nomenclatures, since complications might arise. Most ambiguities in the 168 alignment/nomenclature arise due to insertions and/or deletions (indels). To avoid ambiguities, 169 facilitate haplotype identification and their assignment to existent haplogroups or to new 170 haplogroups, phylogenetic-based nomenclature guidelines have been proposed. The phylogenetic 171 approach provides an evolutionary based view of global mtDNA diversity that is scientifically 172 sound because all mtDNA lineages derive from a common maternal ancestor. The phylogenetic 173 notation of mtDNA haplogroups can be based on maximum parsimony or maximum likelihood 174 analysis of mutations present in sequences from the control region or in mitogenomes (for 175 comprehensive reviews in phylogenetic reconstruction methods see (Bianchi \& Liò, 2007; De 176 Bruyn, Martin, \& Lefeuvre, 2014). The most comprehensive repository of mtDNA genomes is 177 Phylotree (www.phylotree.org) a website that also provides the reference phylogenetic tree 178 describing the worldwide human mitochondrial DNA variation (van Oven \& Kayser, 2008). The 179 phylogenetic tree shown in Phylotree is regularly updated with new haplogroups as found by 180 maximum parsimony analysis of new mtDNA haplotypes using the mtPhyl software 181 (https://sites.google.com/site/mtphyl/home) (van Oven, 2015). A maximum likelihood approach 182 for mtDNA haplogroup classification named EMMA has been recently described by Röck and 183 collaborators (Röck, Dür, Van Oven, \& Parson, 2013).

184 Variants flanking long $\mathrm{C}$ tracts are subject to sequence-specific conventions. The long $\mathrm{C}$ tracts of 185 HVS-I and HVS-II should always be scored with $16189 \mathrm{C}$ and 310C, respectively. Length 186 variation of the short A tract preceding 16184 should be notated preferring transversions unless 187 the phylogeny suggests otherwise. Regarding deletions, these are recorded by the number of the 188 base(s) that is missing, with respect to the rCRS, followed by DEL or del or (-) (for example 249 
189 DEL or 249 del or 249-). When any of the four bases are observed, N notation should be used. 190 Indels should be placed 3' with respect to the light strand unless the phylogeny suggests 191 otherwise. For example, if the bases beyond the position 309 were out of the register by one base 192 due to the insertion of a $\mathrm{C}$ the mutation is designated as 309.1C. Two $\mathrm{C}$ insertions are designated 193 as $309.1 \mathrm{C}$ and $309.2 \mathrm{C}$. Important tools to assist with the notation of mtDNA sequences are 194 available at http://empop.org/. These notations are used for storing haplotypes in the EMPOP 195 database and have also been adopted by the Scientific Working Group on DNA Methods 196 (SWGDAM) in the United States (W. Parson et al., 2014).

197 Overall, the large majority of individuals from African populations, and specially from sub198 Saharan African populations, are categorized into one of the main haplogroup lineages that 199 diverged from macro-haplogroup L - L0, L1, L2, L3, L4, L5 and L6 - (Allard et al., 2005; 200 Bandelt et al., 2001; Behar et al., 2008; Chen et al., 2000; Gonder, Mortensen, Reed, De Sousa, 201 \& Tishkoff, 2007; Pakendorf \& Stoneking, 2005; Rosa, Brehm, Kivisild, Metspalu, \& Villems, 202 2004; van Oven \& Kayser, 2008). On the other hand, more than $90 \%$ of the individuals of the 203 European and USA Caucasian populations are categorized into 10 main haplogroup lineages - H, 204 I, J, K, M, T, U, V, W and X - (Allard, Miller, Wilson, Monson, \& Budowle, 2002; Behar et al., 205 2008; Budowle et al., 2003; Pakendorf \& Stoneking, 2005; Torroni et al., 1996). Concerning to 206 African-American populations, the most commonly observed haplogroups are L2a, L1c, L1b and 207 L3b (Allard et al., 2005). The main haplogroups found in individuals from Asian populations are 208 haplogroups M and N (Allard, Wilson, Monson, \& Budowle, 2004; Kivisild, 2015). 


\section{Mitochondrial DNA Typing Guidelines}

211 In 2014 the DNA Commission of the International Society of Forensic Genetics (ISFG)

212 published updated guidelines and recommendations concerning mitochondrial DNA typing.

213 These guidelines referred to good laboratory practices, targeted region, amplification and 214 sequencing ranges, reference sequence, alignment and notation, heteroplasmy, haplogrouping of 215 mtDNA sequences, and databases and database searches. In Table 1 we present the 16 216 recommendations of ISFG. Overall, these are the main guidelines concerning the application of 217 mtDNA polymorphisms in human identification, which are regularly revised and published by 218 the International Society of Forensic Genetics (Bär et al., 2000; W. Parson et al., 2014; Prinz et 219 al., 2007; Tully et al., 2001).

220

221

\section{Mitochondrial DNA Sequencing Methodologies}

222

223

224

225

226

227

228

229

230

231

232

In 1977 Sanger presented the first DNA sequencing technology (Sanger, Nicklen, \& Coulson, 1977), also called the chain termination method and now known as first generation sequencing. The incorporation of ddNTPs in newly synthesized DNA strands results in termination of the elongation process and correspondent knowledge about the specific nucleotide present at the sequence at each position. Sanger sequencing method can produce reads from 25 up to 1200 nucleotides, allowing the read of a maximum of $96 \mathrm{~kb}$ nucleotides in 2 hours.

Since 2005 new sequencing methods, also known as next generation sequencing (NGS) methods, have been developed (Bruijns, Tiggelaar, \& Gardeniers, 2018). Sequencing by synthesis methods such as Roches' - 454 Pyrosequencing -, and Illuminas'- HiSeq -, allow sequencing up to 80 million base pairs in 2 hours or up to 6 billion base pairs in 1- 2 weeks (Mascher, Wu, St. Amand, Stein, \& Poland, 2013; Pukk et al., 2015). Sequencing by hybridization and ligation such 
233 as ABIs'-SOLiD 3plus platform -, yields 60 gigabases of usable DNA data per run. With these

234 massive parallel sequencing (MPS) technologies, sequenced DNA fragments can range from 35-

23575 nucleotides as in the SOLiD technology (Bruijns et al., 2018; Ondov et al., 2010; Shendure et 236 al., 2005), to 100-1,000 nucleotides as in 454 Pyrosequencing (Bruijns et al., 2018; Dames, 237 Durtschi, Geiersbach, Stephens, \& Voelkerding, 2010). Ion Torrent's Personal Genome 238 Machine $^{\mathrm{TM}}$ (PGM) uses a detection methodology based in $\mathrm{pH}$ change upon addition of a 239 nucleotide to a sequence (Rothberg et al., 2011). When this happens protons are released 240 generating an electric signal that is proportional to the amount of protons released. Data 241 collection is carried out by a complementary metal-oxide semiconductor (CMOS) sensor array 242 chip with the sensor surface present at the bottom of the well plate, and these chips can measure 243 millions to billions of simultaneous sequencing reactions (Liu et al., 2014). Finally, MinION 244 (Oxford Nanopore Technologies), a portable real-time sequencing device, allows ultra-long read 245 lengths (hundreds of $\mathrm{kb}$ ) albeit with lower accuracy (Oikonomopoulos, Wang, Djambazian, 246 Badescu, \& Ragoussis, 2016).

247 The NGS technologies have been quickly applied in forensics (Bruijns et al., 2018). For example, 248 Ion Torrent's PGM system has been used for sequencing complete mitogenomes (Walther 249 Parson et al., 2013) and to study heteroplasmy (Magalhães et al., 2015) in the forensic context. 250 Although PGM proved to be sensitive and accurate at detecting and quantifying mixture and 251 heteroplasmy, there were some problems in the coverage of the mtDNA genome with some 252 regions presenting extreme strand bias, and presenting false positives mostly generated by 253 alignment problems in the analysis algorithms. More recently Ion S5 System (Thermo Fisher 254 Scientific) and MiSeq FGx Desktop Sequencer (Illumina) were used to evaluate the Precision ID 255 mtDNA Whole Genome Panel (Woerner et al., 2018). Both sequencing systems provided 
256 consistent estimation of mtDNA haplotypes. Many other studies on the use of NGS technologies

257 for forensic genetics and mtDNA analysis have been published (Chaitanya et al., 2015;

258 Churchill, Stoljarova, King, \& Budowle, 2018; Hollard et al., 2017; Just, Irwin, \& Parson, 2015;

259 Just, Scheible, Fast, Sturk-Andreaggi, Higginbotham, et al., 2014; Just, Scheible, Fast, Sturk-

260 Andreaggi, Röck, et al., 2014; Lopopolo, Børsting, Pereira, \& Morling, 2016; Ma et al., 2018;

261 Marshall et al., 2017; Ovchinnikov, Malek, Kjelland, \& Drees, 2016; Park et al., 2017;

262 Templeton et al., 2013; Young, King, Budowle, \& Armogida, 2017). However, further validation

263 studies and specialized software functionality tailored to forensic practice should be produced in

264 order to facilitate the incorporation of NGS processing into standard casework applications

265 (Amorim \& Pinto, 2018; Peck et al., 2016). In the meantime, and according to current

266 international guidelines (W. Parson et al., 2014; Prinz et al., 2007), Sanger sequencing still

267 continues to be an adequate method for mtDNA analysis for forensic human identification, and is

268 used in most casework laboratories worldwide (Ballard, 2016). Some forensic laboratories

269 perform Sanger sequencing for HVI and HVII fragments, while others have already extended the

270 study to the HVIII fragment and, in recent years, most of the forensic laboratories are

271 introducing the amplification of the entire control region as routine methodology (Chaitanya et

272 al., 2016; Poletto, Malaghini, Silva, Bicalho, \& Braun-Prado, 2019; Turchi et al., 2016; Yasmin,

273 Rakha, Noreen, \& Salahuddin, 2017). Attempting to improve the power of mtDNA in human

274 identification, over the past decade some studies have been focused in the extension of the 275 analyses to the whole mtDNA genome (Duan et al., 2018; Strobl, Eduardoff, Bus, Allen, \& 276 Parson, 2018; Woerner et al., 2018). Nevertheless, it should be stressed that while the 277 information from the entire mtDNA genome can contribute to refine the haplogroup obtained 278 with the study of HVI, HVII and HVII fragments or the entire control region, it is not supposed 
279 to change the previous results to a different haplogroup of a completely different geographic 280 ancestry.

281

282

\section{Mitochondrial DNA Population Data and Databases}

283

284

285

286

287

288

289

290

291

292

293

294

295

296

297

298

299

300

301

When two mtDNA sequences, one from an evidence sample and another from a reference sample, cannot be excluded as being originated from the exact same source, it is necessary to convey some information concerning the rarity of the mtDNA profile. The current practice is to count how many times a specific sequence is observed within a population database(s) (Budowle et al., 1999). Overall, the population databases that are used in forensics comprehend several convenience samples, representing the major population groups of the potential contributors in terms of evidence.

The most important mtDNA haplotypes database is the EDNAP Mitochondrial DNA Population Database (EMPOP, www.empop.org) (Walther Parson \& Dür, 2007). In its early stages, EMPOP was designed and envisioned to serve as a reference population database, specifically to be used in the evaluation of the mtDNA evidence around the world, aiming to provide the highest quality mtDNA data. The architecture of this online database and its analysis tools have evolved over the last few years, even though the main emphasis of the EMPOP database remains to be mtDNA data quality. Therefore, and as a direct consequence, EMPOP not only serves as a reference population database, but also as a quality-control tool for scientists in forensic genetics, as well as in other disciplines. Finally, and even though there is a significant number of high-quality reference population databases for forensic comparisons, EMPOP is the most comprehensive resource, especially from the standpoint of the populations that are represented in such database (W. Parson et al., 2014).

Peer) reviewing PDF | (2019:01:34345:2:2:NEW 7 Jun 2019) 
302 EMPOP uses SAM, a string-based search algorithm that converts query and database sequences

303 into alignment-free nucleotide strings and thus guarantees that a haplotype is found in a database

304 query regardless of its alignment. SAM-E, an updated version of SAM that considers block

305 InDels as phylogenetic events, is used currently. At EMPOP, the tool haplogroup browser

306 represents all the established Phylotree haplogroups in convenient searchable format and

307 provides the number of EMPOP sequences assigned to the respective haplogroups by estimating

308 mitochondrial DNA haplogroups using the maximum likelihood approach EMMA (Röck et al.,

309 2013). For multiple possible haplogroups, most recent common ancestor (MRCA) haplogroups

310 are provided.

311 As mentioned before, PhyloTree provides an updated comprehensive phylogeny of global human

312 mtDNA variation, based on both coding and control region mutations (van Oven \& Kayser,

313 2008). The complete mtDNA phylogenetic tree includes previously published as well as newly

314 identified haplogroups, is continuously and regularly updated, and is available online at

315 http://www.phylotree.org. At EMPOP the geographical haplogroup patterns are provided via

316 maps to visualize and better understand their geographical distribution (Figure 2).

317 Another important human mtDNA database is Mitomap (Ruiz-Pesini et al., 2007). In 1996, this

318 database developed into an online database, www.mitomap.org, containing published human

319 mtDNA variation along with geographic and disease specific variants. Currently, Mitomap is

320 manually curated, frequently updated and a functionally rich resource, presenting high-quality

321 human mtDNA data for clinicians, investigators and geneticists (Ruiz-Pesini et al., 2007).

322 Mitomap has three main categories for usage. It contains some background information

323 regarding the human mitochondrial DNA, such as the general representation of mtDNA, 
324 haplogroups and their frequencies and illustrations of mtDNA, among others. Furthermore, users

325 can also find information about other mtDNA-specific databases, tools and useful resources.

326 Mitomap stores the annotated listing of the mtDNA variants from both healthy individuals and

327 patients. The frequencies of the variants are calculated from human mitogenomes retrieved from

328 the GenBank. Therefore, users can retrieve information about the loci, the nucleotide change, the

329 codon position and the number, among others, and download the most important data in different 330 file formats.

331 Mitomap contains the Mitomaster analysis tool, currently providing the Application

332 Programming Interface for it. The main function of this tool is to allow the identification of

333 polymorphic positions, the calculation of variant statistics and the assignment of haplogroups to

334 complete or partial mitogenomes. Such query might be performed by recurring to mtDNA

335 sequences, to GenBank identifiers or to single nucleotide variants (Brandon et al., 2009).

336 From another perspective, ethical and legal problems may arise in the implementation of mtDNA

337 databases. The informative potential which the analysis of mtDNA entails can generate privacy

338 questions (Guillen, Lareu, Pestoni, Salas, \& Carracedo, 2000; H. M. Wallace, Jackson, Gruber,

$339 \&$ Thibedeau, 2014). Mitochondrial diseases affect between 1 in 4,000 and 1 in 5,000 people. In

340 most people, primary mitochondrial disease is a genetic condition that can be inherited.

341 Information about the mitochondrial genome composition may therefore enable the identification

342 of the current or future state of health of an individual. For this reason, the analysis of mtDNA

343 must be carried out only on non-coding regions, which have not been associated with any kind of

344 disease or phenotypical information. 


\section{Mitochondrial DNA in Forensic Human Identification}

347 In the context of forensic analysis, both mtDNA sequences of a reference sample and an

348 evidence sample(s) are compared. When the sequences are unequivocally different, the

349 conclusion is that they can be excluded as being originated from the same source. Although not

350 stated in any research paper or guideline text, forensic routine laboratories tend to accept as an

351 exclusion scenario when more nucleotide differences exist between the two sequences. If the

352 mtDNA sequences are identical, the samples can't be excluded since they must have the same

353 origin or derive from the same maternal lineage. Similarly, samples can't be excluded when

354 heteroplasmy is observed at the same nucleotide positions in both samples. When one sample is

355 heteroplasmic and the other is homoplasmic but they both share at least one mtDNA species, the 356 samples can't be excluded since they may have the same origin. Several authors have suggested

357 that samples with mtDNA with one-base difference should be further evaluated, mainly 358 regarding their rate of mutation (Alonso et al., 2002; Bär et al., 2000; Holland \& Parsons, 1999; 359 Parson et al., 2014; Tully et al., 2001).

360 At this section we present some selected published cases of human identification with mtDNA. 361 Table 2 summarizes the selected published cases. In 1991, Stoneking and collaborators presented 362 the first report of successful application of the mtDNA typing to a case that involved the 363 individual identification of skeletal remains (Stoneking, Hedgecock, Higuchi, Vigilant, \& Erlich, 364 1991). This was the case of a 3-year-old child disappeared from her parents' house in October of 365 1984. In March of 1986, the skeletal remains of a human child were found in the desert, 2 miles 366 away from the parents' residence. Using hybridization with 23 sequence-specific oligonucleotide 367 probes (SSO) targeting nine regions of HV1 and HV2 on the control region, they found that the 
368 skeletal sample and the mother shared the same mtDNA types, corroborating that those skeletal

369 remains were of the missing child. Moreover, they anticipated that the mtDNA typing would be

370 valuable not only in linking biological remains to missing individuals, but also in the analysis of

371 material in sexual assault cases.

372 In July of 1990, the body of a female, in a quite advanced state of decomposition, was discovered

373 in an open field. Despite being impossible to identify the remains by analyzing the individual's

374 clothes and fingerprints, her dentition was consistent with old dental records of a missing person

375 from the same region. Some fragments of the heel bone and fibula, plus samples of the hair and

376 skin, were provided for the DNA analysis, as well as a blood sample from a putative sister of the

377 deceased. In 1992, Sullivan and collaborators attempted the identification of the highly

378 decomposed remains of the corpse, amplifying and directly sequencing 2 hypervariable segments

379 within HV1 and HV2 in the mtDNA (Sullivan, Hopgood, \& Gill, 1992). No statistical value was

380 given to the evidence, since no database of the British population sequences were available at

381 that time. Still, no differences were found between both sequences, the blood of the putative

382 sister and the bone of the corpse, indicating they were sisters.

383 Perhaps the most well-known lineage study using mtDNA sequencing is related to the 384 identification of Tsar Nicholas II's bones. Gill and collaborators, in 1994 (Gill et al., 1994), and

385 Ivanov and collaborators, in 1996 (Ivanov et al., 1996), compared the sequences of HV1 and 386 HV2 fragments of the mtDNA obtained from the putative bones of the Tsar with those of Tsar 387 living maternal relatives, Countess Xenia Cheremeteff-Sfiri and the Duke of Fife. It was found 388 that the sequences were very similar, corroborating the hypothesis that the bone remains were of 389 Tsar Nicholas II. 
390 In a distinct scenario, Deng et al. (Deng et al., 2005) used direct sequencing of the HV1 and HV2

391 fragments of the mtDNA control region to identify Tsunami victims in Thailand in 2004. This

392 tsunami killed nearly 5,400 people in Southern Thailand, including foreign tourists and local

393 residents. They succeeded in obtaining fully informative results for mtDNA markers (HV1 and

394 HV2) from 258 tooth samples with a success rate of $51 \%(258 / 507)$.

395 More recently, in 2010, Ríos and collaborators (Ríos, García-Rubio, Martínez, Alonso, \& 396 Puente, 2010) used direct sequencing of the HV1 and HV2 fragments of the mtDNA control 397 region to identify human skeletal remains that were exhumed from a mass grave from the 398 Spanish Civil War (1936-1939). There was a match between the mtDNA profiles of the 399 biologically youngest skeleton and the sister of the youngest person that was presumptively 400 known to be buried in the grave, allowing the identification of that person.

401 Also in 2010, Piccinini and collaborators (Piccinini et al., 2010) attempted to identify the 402 remains of a famous World War One Italian soldier that was killed in a battle along the Italian 403 front in 1915. Like previous studies, they used the direct sequencing of the HV1 and HV2 404 fragments of the mtDNA control region to define single mtDNA haplotypes. The availability of 405 the offspring maternal lineage allowed the mtDNA analysis, which presented a clear exclusion 406 scenario: the remains did not belong to the supposed war hero.

407 In 2012, a skeleton was excavated at the site of the Grey Friars friary, in Leicester, which is the 408 last-known resting place of King Richard III (King et al., 2014). To determine if the remains 409 belonged to King Richard III, the HV1, HV2 and HV3 regions of the mtDNA of the skeletal 410 remains and of the living relatives of King Richard III were sequenced and compared. There was 411 a perfect match between the sequences indicating that the remains belong to King Richard III. 
412 The communist period in Poland during 1944-1956 resulted in the death of more than 50,000

413 people, who were buried in secret. One mass grave was found at the cemetery Powazki Military,

414 in Warsaw, Poland. In 2016, Ossowski and collaborators (Ossowski et al., 2016) identified 50

415 victims, specifically by using autosomal, Y-STR and direct sequencing of the HV1 and HV2

416 fragments of the mtDNA control region.

417 In 2016, among the first studies on human identification with mtDNA using massive parallel 418 sequencing, Ambers and collaborators proposed a protocol that includes the study of ten regions 419 of mtDNA for the identification of historical human remains with forensic genetic markers 420 (Ambers et al., 2016). They studied a 140-year-old human skeletal remains discovered at a 421 historical site in Deadwood, South Dakota, United States. The remains were in an unmarked 422 grave and there were no records available regarding the identity of the individual. The mtDNA 423 profiles of the unidentified skeletal remains obtained with their method were consistent with $\mathrm{H} 1$ 424 haplogroup. This haplogroup is the most common in Western Europe. The ancestry-informative 425 nuclear SNPs also studied in this case indicated a European background. These genetic results 426 are consistent with the findings of previous anthropological report which determined that the 427 Deadwood unidentified skeletal remains belong to a male of European ancestry.

428 In 2017, the victims' remains from the World Trade Center terrorism act, which occurred in 429 September 11 of 2001, were still being identified by using the mtDNA sequencing technology, 430 among other techniques, with protocols and guidelines as recommended by the International 431 Society for Forensic Genetics (Goodwin, 2017). 
434 Over the last 25 years, mtDNA typing has been widely used around the world to solve several 435 human identification related issues in violent crimes, lesser crimes, acts of terrorism, mass 436 disasters and missing persons' cases. The progress in mtDNA typing has been overwhelming, 437 going from the examination of small fragments in a matter of days to sequencing multiple entire 438 mtDNA genomes in a couple of hours. Being a lineage genetic marker, mtDNA genome can 439 provide information about ancestors, including health/disease information. Even though many 440 would readily accept that there are good reasons for researchers to obtain information about an 441 unknown suspect's potential ancestral background, many still find the potential to determine 442 genetic dispositions to certain disorders as being unacceptable. Hence, new technologies that 443 enable mitogenome sequencing must be wisely used and for the reasons that they are intended, 444 considering their specific focus and contribution within the field of forensic human 445 identification.

446 Some concerns still remain regarding admissibility of mtDNA analysis in court especially related 447 with the issue of heteroplasmy and, more recently, with the possibility of biparental inheritage. 448 The complete elucidation of molecular mechanisms driving biparental inheritage of mtDNA, the 449 ability to determine the situations where this is likely to occur, and the ability to identify and 450 characterize heteroplasmy with high accuracy, are important issues that need to be addressed in 451 order to ensure the robustness of mtDNA as an important and alternative tool in forensic human 452 identification.

453

454 Acknowledgements

455 None to report. 


\section{References}

458 Allard, M. W., Miller, K., Wilson, M., Monson, K., \& Budowle, B. (2002). Characterization of

459 the Caucasian haplogroups present in the SWGDAM forensic mtDNA dataset for 1771

460 human control region sequences. Scientific Working Group on DNA Analysis Methods.

$461 \quad$ Journal of Forensic Sciences, 47(6), 1215-1223.

462 Allard, M. W., Polanskey, D., Miller, K., Wilson, M. R., Monson, K. L., \& Budowle, B. (2005).

463 Characterization of human control region sequences of the African American SWGDAM

464 forensic mtDNA data set. Forensic Science International, 148(2-3), 169-179.

465 https://doi.org/10.1016/j.forsciint.2004.06.001

466 Allard, M. W., Wilson, M. R., Monson, K. L., \& Budowle, B. (2004). Control region sequences

467 for East Asian individuals in the Scientific Working Group on DNA Analysis Methods

468 forensic mtDNA data set. Legal Medicine, 6(1), 11-24.

469 https://doi.org/10.1016/j.legalmed.2003.08.004

470 Alonso, A., Salas, A., Albarrán, C., Arroyo, E., Castro, A., Crespillo, M., Gómez, J. (2002).

471 Results of the 1999-2000 collaborative exercise and proficiency testing program on

472 mitochondrial DNA of the GEP-ISFG: An inter-laboratory study of the observed variability

473 in the heteroplasmy level of hair from the same donor. Forensic Science International,

$474 \quad$ 125(1), 1-7. https://doi.org/10.1016/S0379-0738(01)00602-8

475 Ambers, A. D., Churchill, J. D., King, J. L., Stoljarova, M., Gill-King, H., Assidi, M., Budowle,

476 B. (2016). More comprehensive forensic genetic marker analyses for accurate human

477 remains identification using massively parallel DNA sequencing. BMC Genomics, 17(Suppl

478 9). https://doi.org/10.1186/s12864-016-3087-2

479 Amorim, A., \& Pinto, N. (2018). Big data in forensic genetics. Forensic Science International: 
480

481

482

483

484

485

486

487

488

489

490

491

492

493

494

495

496

497

498

499

500

501

502

Genetics, 37(August), 102-105. https://doi.org/10.1016/j.fsigen.2018.08.001

Anderson, S., Bankier, A. T., Barrell, B. G., de Bruijn, M. H. L., Coulson, A. R., Drouin, J., Young, I. G. (1981). Sequence and organization of the human mitochondrial genome. Nature, 290(5806), 457-465. https://doi.org/10.1038/290457a0

Andrews, R. M., Kubacka, I., Chinnery, P. F., Lightowlers, R. N., Turnbull, D. M., \& Howell, N. (1999). Reanalysis and revision of the Cambridge reference sequence for human mitochondrial DNA. Nature Genetics, 23(2), 147. https://doi.org/10.1038/13779

Ballard, D. (2016). Analysis of Mitochondrial Control Region Using Sanger Sequencing (pp. 143-155). Humana Press, New York, NY. https://doi.org/10.1007/978-1-4939-3597-0_12

Bandelt, H. J., Alves-Silva, J., Guimarães, P. E. M., Santos, M. S., Brehm, A., Pereira, L., Pena, S. D. J. (2001). Phylogeography of the human mitochondrial haplogroup L3e: A snapshot of African prehistory and Atlantic slave trade. Annals of Human Genetics, 65(6), 549-563. https://doi.org/10.1046/j.1469-1809.2001.6560549.x

Bär, W., Brinkmann, B., Budowle, B., Carracedo, A., Gill, P., Holland, M., Wilson, M. (2000). Guidelines for mitochondrial DNA typing. DNA Commission of the International Society for Forensic Genetics. Vox Sang, 79(2), 121-125.

Behar, D. M., Villems, R., Soodyall, H., Blue-Smith, J., Pereira, L., Metspalu, E., Rosset, S. (2008). The dawn of human matrilineal diversity. American Journal of Human Genetics, 82(5), 1130-1140. https://doi.org/10.1016/j.ajhg.2008.04.002

Bendall, K. E., Macaulay, V. A., \& Sykes, B. C. (1997). Variable levels of a heteroplasmic point mutation in individual hair roots. American Journal of Human Genetics, 61(6), 1303-1308. https://doi.org/10.1086/301636

Bendall, K. E., \& Sykes, B. C. (1995). Length heteroplasmy in the first hypervariable segment of 
504 Bianchi, L., \& Liò, P. (2007). Forensic DNA and bioinformatics. Briefings in Bioinformatics, $505 \quad 8(2), 117-128$. https://doi.org/10.1093/bib/bbm006

506 Brandon, M. C., Ruiz-pesini, E., Mishmar, D., Procaccio, V., Marie, T., Nguyen, K. C., 507 Douglas, C. (2009). MITOMASTER - A Bioinformatics Tool For the Analysis of 508 Mitochondrial DNA Sequences. Human Mutation, 30(1), 1-6.

509 https://doi.org/10.1002/humu.20801.MITOMASTER

510 Bruijns, B., Tiggelaar, R. M., \& Gardeniers, H. J. G. E. (2018). Massively parallel sequencing 511 techniques for forensics: A review. Electrophoresis, 1-13.

$512 \quad$ https://doi.org/10.1002/elps.201800082

513 Budowle, B., Allard, M. W., Wilson, M. R., \& Chakraborty, R. (2003). FORENSICS AND

514 MITOCHONDRIAL DNA: Applications, Debates, and Foundations*. Annual Review of 515 Genomics and Human Genetics, 4(1), 119-141.

516 https://doi.org/10.1146/annurev.genom.4.070802.110352

517 Budowle, B., Wilson, M. R., DiZinno, J. A., Stauffer, C., Fasano, M. A., Holland, M. M., \& 518 Monson, K. L. (1999). Mitochondrial DNA regions HVI and HVII population data. $519 \quad$ Forensic Science International, 103(1), 23-35. https://doi.org/10.1016/S0379$520 \quad 0738(99) 00042-0$

521 Buffoli, B., Rinaldi, F., Labanca, M., Sorbellini, E., Trink, A., Guanziroli, E., Rodella, L. F.

522 (2013). The human hair: from anatomy to physiology. International Journal of

523 Dermatology, (November 2015), 1-11. https://doi.org/10.1111/ijd.12362

524 Case, J., \& Wallace, D. (1981). Maternal inheritance of mitochondrial DNA polymorphisms in 525 cultured human fibroblasts. Somatic Cell Genetics, 7(1), 103-108. 
526 Chaitanya, L., Ralf, A., van Oven, M., Kupiec, T., Chang, J., Lagacé, R., \& Kayser, M. (2015).

527 Simultaneous Whole Mitochondrial Genome Sequencing with Short Overlapping

528 Amplicons Suitable for Degraded DNA Using the Ion Torrent Personal Genome Machine.

529 Human Mutation, 36(12), 1236-1247. https://doi.org/10.1002/humu.22905

530 Chaitanya, L., van Oven, M., Brauer, S., Zimmermann, B., Huber, G., Xavier, C., Kayser, M.

531 (2016). High-quality mtDNA control region sequences from 680 individuals sampled across

532 the Netherlands to establish a national forensic mtDNA reference database. Forensic

533 Science International. Genetics, 21, 158-167. https://doi.org/10.1016/j.fsigen.2015.12.002

534 Chen, Y.-S., Olckers, A., Schurr, T. G., Kogelnik, A. M., Huoponen, K., \& Wallace, D. C.

535 (2000). mtDNA Variation in the South African Kung and Khwe - and Their Genetic

536 Relationships to Other African Populations. The American Journal of Human Genetics,

537 66(4), 1362-1383. https://doi.org/10.1086/302848

538 Churchill, J. D., Stoljarova, M., King, J. L., \& Budowle, B. (2018). Massively parallel

539 sequencing-enabled mixture analysis of mitochondrial DNA samples. International Journal

540 of Legal Medicine, 132(5), 1263-1272. https://doi.org/10.1007/s00414-018-1799-3

541 Comas, D., Paabo, S., \& Bertranpetit, J. (1995). Heteroplasmy in the control region of human

542 mitochondrial DNA. Genome Research, 5(1), 89-90. https://doi.org/10.1101/gr.5.1.89

543 Cummins, J. M., Wakayama, T., \& Yanagimachi, R. (1997). Fate of microinjected sperm

544 components in the mouse oocyte and embryo. Zygote, 5(4), 301-308.

$545 \quad$ https://doi.org/10.1017/S0967199400003889

546 Dames, S., Durtschi, J., Geiersbach, K., Stephens, J., \& Voelkerding, K. V. (2010). Comparison

547 of the illumina genome analyzer and roche 454 GS FLX for resequencing of hypertrophic

548 cardiomyopathy-associated genes. Journal of Biomolecular Techniques, 21(2), 73-80. 
549 De Bruyn, A., Martin, D. P., \& Lefeuvre, P. (2014). Phylogenetic Reconstruction Methods: An

550 Overview (pp. 257-277). Humana Press, Totowa, NJ. https://doi.org/10.1007/978-1-62703-

$551 \quad 767-9+13$

552 Deng, Y. J., Li, Y. Z., Yu, X. G., Li, L., Wu, D. Y., Zhou, J., Yu, J. (2005). Preliminary DNA

553 identification for the tsunami victims in Thailand. Genomics, Proteomics and

554 Bioinformatics, 3(3), 143-157. https://doi.org/10.1016/S1672-0229(05)03020-2

555 Duan, M., Chen, L., Ge, Q., Lu, N., Li, J., Pan, X., Wilson, M. R. (2018). Evaluating

556 heteroplasmic variations of the mitochondrial genome from whole genome sequencing data.

557 Future Science OA, 699(9), FSO336. https://doi.org/10.4155/fsoa-2018-0059

558 Elson, J. L., Samuels, D. C., Turnbull, D. M., \& Chinnery, P. F. (2001). Random Intracellular

559 Drift Explains the Clonal Expansion of Mitochondrial DNA Mutations with Age. The

560 American Journal of Human Genetics, 68(3), 802-806. https://doi.org/10.1086/318801

561 Giles, R. E., Blanc, H., Cann, H. M., \& Wallace, D. C. (1980). Maternal inheritance of human

562 mitochondrial DNA. Proceedings of the National Academy of Sciences of the United States

563 of America, 77(11), 6715-6719. https://doi.org/10.1073/pnas.77.11.6715

564 Gill, P., Ivanov, P. L., Kimpton, C., Piercy, R., Benson, N., Tully, G., Sullivan, K. (1994).

565 Identification of the remains of the Romanov family by DNA analysis. Nature Genetics,

$566 \quad 6(2), 130-135$. https://doi.org/10.1038/ng0294-130

567 Gonder, M. K., Mortensen, H. M., Reed, F. A., De Sousa, A., \& Tishkoff, S. A. (2007). Whole-

568 mtDNA genome sequence analysis of ancient african lineages. Molecular Biology and

569 Evolution, 24(3), 757-768. https://doi.org/10.1093/molbev/ms1209

570 Goodwin, W. H. (2017). The use of forensic DNA analysis in humanitarian forensic action: The 571 development of a set of international standards. Forensic Science International, 278, 221- 
573 Greenberg, B. D., Newbold, J. E., \& Sugino, A. (1983). Intraspecific nucleotide sequence

574 variability surrounding the origin of replication in human mitochondrial DNA. Gene, 21(1-

575 2), 33-49. https://doi.org/10.1016/0378-1119(83)90145-2

576 Guillen, M., Lareu, M. V., Pestoni, C., Salas, A., \& Carracedo, A. (2000). Ethical-legal problems 577 of DNA databases in criminal investigation. Journal of Medical Ethics, 26(4), 266-271.

$578 \quad$ https://doi.org/10.1136/jme.26.4.266

579 Gyllensten, U., Wharton, D., Josefsson, A., \& Wilson, A. C. (1991). Paternal inheritance of 580 mitochondrial DNA in mice. Nature, 352(6332), 255-257.

$581 \quad$ https://doi.org/10.1038/352255a0

582 Holland, M. M., \& Parsons, T. J. (1999). Mitochondrial DNA Sequence Analysis - Validation $583 \quad$ and Use for Forensic Casework. Forensic Science Rev, 11(1), 21-50.

584 Hollard, C., Keyser, C., Delabarde, T., Gonzalez, A., Vilela Lamego, C., Zvénigorosky, V., \& 585 Ludes, B. (2017). Case report: on the use of the HID-Ion AmpliSeq ${ }^{\mathrm{TM}}$ Ancestry Panel in a $586 \quad$ real forensic case. International Journal of Legal Medicine, 131(2), 351-358.

587 https://doi.org/10.1007/s00414-016-1425-1

588 Hutchison, C. A., Newbold, J. E., Potter, S. S., \& Edgell, M. H. (1974). Maternal inheritance of 589 mammalian mitochondrial DNA. Nature, 251(October 1974), 536-538.

590 Ivanov, P. L., Wadhams, M. J., Roby, R. K., Holland, M. M., Weedn, V. W., Parsons, T. J., \& 591 Ivanov PL, Wadhams MJ, Roby RK, Holland MM, W. V. \& P. T. (1996). Mitochondrial 592 DNA sequence heteroplasmy in the Grand Duke of Russia Georgij Romanov establishes the 593 authenticity of the remains of Tsar Nicholas II. Nat Genet., 12(12), 417-420.

$594 \quad$ https://doi.org/10.1038/ng0496-417 
595 Just, R. S., Irwin, J. A., \& Parson, W. (2015). Mitochondrial DNA heteroplasmy in the emerging 596 field of massively parallel sequencing. Forensic Science International: Genetics, 18, 131597 139. https://doi.org/10.1016/j.fsigen.2015.05.003

598 Just, R. S., Scheible, M. K., Fast, S. A., Sturk-Andreaggi, K., Higginbotham, J. L., Lyons, E. A., 599 Irwin, J. A. (2014). Development of forensic-quality full mtGenome haplotypes: Success 600 rates with low template specimens. Forensic Science International: Genetics, 10(1), 73-79. $601 \quad$ https://doi.org/10.1016/j.fsigen.2014.01.010

602 Just, R. S., Scheible, M. K., Fast, S. A., Sturk-Andreaggi, K., Röck, A. W., Bush, J. M., Irwin, J. 603 A. (2014). Full mtGenome reference data: Development and characterization of 588 604 forensic-quality haplotypes representing three U.S. populations. Forensic Science 605 International: Genetics, 14, 141-155. https://doi.org/10.1016/j.fsigen.2014.09.021

606 Kefi-Ben Atig, R., Hsouna, S., Beraud-Colomb, E., \& Abdelhak, S. (2009). ADN mitochondrial: 607 propriétés et applications. Archives de l'Institut Pasteur de Tunis, 86(1-4), 3-14.

608 King, T. E., Fortes, G. G., Balaresque, P., Thomas, M. G., Balding, D., Delser, P. M., Schürer, 609 K. (2014). Identification of the remains of King Richard III. Nature Communications, 5, 1$610 \quad 8$. https://doi.org/10.1038/ncomms6631

611 Kivisild, T. (2015). Maternal ancestry and population history from whole mitochondrial 612 genomes. Investigative Genetics, 6(1), 1-10. https://doi.org/10.1186/s13323-015-0022-2

613 Liu, L., Li, Y., Li, S., Hu, N., He, Y., Pong, R., Law, M. (2014). Comparison of next-generation 614 sequencing systems. The Role of Bioinformatics in Agriculture, 2012, 1-25. 615 https://doi.org/10.1201/b16568

616 Lopopolo, M., Børsting, C., Pereira, V., \& Morling, N. (2016). A study of the peopling of 617 Greenland using next generation sequencing of complete mitochondrial genomes. American 
618 Journal of Physical Anthropology, 161(4), 698-704. https://doi.org/10.1002/ajpa.23074

619 Lott, M. T., Derbeneva, O., Xie, H. M., \& Wallace, D. C. (2014). NIH Public Access, 1(123), 1-49.

620 https://doi.org/10.1002/0471250953.bi0123s44.mtDNA

621 Luo, S., Valencia, C. A., Zhang, J., Lee, N.-C., Slone, J., Gui, B., Huang, T. (2018). Biparental

622 Inheritance of Mitochondrial DNA in Humans. Proceedings of the National Academy of

623 Sciences, 115(51), 13039-13044. https://doi.org/10.1073/PNAS.1810946115

624 Lutz, S., Wittig, H., Weisser, H. J., Heizmann, J., Junge, A., Dimo-Simonin, N., Augustin, C.

625 (2000). Is it possible to differentiate mtDNA by means of HVIII in samples that cannot be

626 distinguished by sequencing the HVI and HVII regions? Forensic Science International,

627 113(1-3), 97-101. https://doi.org/10.1016/S0379-0738(00)00222-X

628 Ma, K., Zhao, X., Li, H., Cao, Y., Li, W., Ouyang, J., Liu, W. (2018). Massive parallel

629 sequencing of mitochondrial DNA genomes from mother-child pairs using the ion torrent

630 personal genome machine (PGM). Forensic Science International: Genetics, 32(November

631 2017), 88-93. https://doi.org/10.1016/j.fsigen.2017.11.001

632 Magalhães, S., Marques, S. L., Alves, C., Amorim, A., Alvarez, L., \& Goios, A. (2015).

633 Evaluation of heteroplasmy detection in the Ion Torrent PGM. Forensic Science

634 International: Genetics Supplement Series, 5, e13-e15.

635 https://doi.org/10.1016/j.fsigss.2015.09.006

636 Marshall, C., Sturk-Andreaggi, K., Daniels-Higginbotham, J., Oliver, R. S., Barritt-Ross, S., \&

637 McMahon, T. P. (2017). Performance evaluation of a mitogenome capture and Illumina

638 sequencing protocol using non-probative, case-type skeletal samples: Implications for the

639 use of a positive control in a next-generation sequencing procedure. Forensic Science

640 International: Genetics, 31(May), 198-206. https://doi.org/10.1016/j.fsigen.2017.09.001

641 Mascher, M., Wu, S., St. Amand, P., Stein, N., \& Poland, J. (2013). Application of Genotyping- 
642 by-Sequencing on Semiconductor Sequencing Platforms: A Comparison of Genetic and

643 Reference-Based Marker Ordering in Barley. PLoS ONE, 8(10), 1-11.

644 https://doi.org/10.1371/journal.pone.0076925

645 Mitchell, S. L., Goodloe, R., Brown-gentry, K., Pendergrass, S. A., Murdock, D. G., \&

646 Crawford, D. C. (2015). Characterization of mitochondrial haplogroups in a large

647 population-based sample from the United States. Human Genetics, 133(7), 861-868.

648 https://doi.org/10.1007/s00439-014-1421-9.Characterization

649 Nass, M. M. K., \& Nass, S. (1963). Intramitochondrial fibers with DNA characteristics. I.

650 Fixation and electron staining reactions. The Journal of Cell Biology, 19, 593-611.

651 Oikonomopoulos, S., Wang, Y. C., Djambazian, H., Badescu, D., \& Ragoussis, J. (2016).

652 Benchmarking of the Oxford Nanopore MinION sequencing for quantitative and qualitative

653 assessment of cDNA populations. Scientific Reports, 6(August), 1-13.

$654 \quad$ https://doi.org/10.1038/srep31602

655 Ondov, B. D., Cochran, C., Landers, M., Meredith, G. D., Dudas, M., \& Bergman, N. H. (2010).

656 An alignment algorithm for bisulfite sequencing using the Applied Biosystems SOLiD

657 System. Bioinformatics, 26(15), 1901-1902. https://doi.org/10.1093/bioinformatics/btq291

658 Ossowski, A., Diepenbroek, M., Kupiec, T., Bykowska-Witowska, M., Zielińska, G.,

659 Dembińska, T., \& Ciechanowicz, A. (2016). Genetic Identification of Communist Crimes'

660 Victims (1944-1956) Based on the Analysis of One of Many Mass Graves Discovered on

661 the Powazki Military Cemetery in Warsaw, Poland. Journal of Forensic Sciences, 61(6),

$662 \quad 1450-1455$. https://doi.org/10.1111/1556-4029.13205

663 Ovchinnikov, I. V., Malek, M. J., Kjelland, K., \& Drees, K. (2016). Whole Human

664 Mitochondrial DNA Sequencing (pp. 157-171). Humana Press, New York, NY. 

https://doi.org/10.1007/978-1-4939-3597-0_13

666 Pakendorf, B., \& Stoneking, M. (2005). Mitochondrial Dna and Human Evolution. Annual 667 Review of Genomics and Human Genetics, 6(1), 165-183.

668 https://doi.org/10.1146/annurev.genom.6.080604.162249

669 Park, S., Cho, S., Seo, H. J., Lee, J. H., Kim, M. Y., \& Lee, S. D. (2017). Entire mitochondrial 670 DNA sequencing on massively parallel sequencing for the Korean population. Journal of 671 Korean Medical Science, 32(4), 587-592. https://doi.org/10.3346/jkms.2017.32.4.587

672 Parson, W., \& Dür, A. (2007). EMPOP-A forensic mtDNA database. Forensic Science 673 International: Genetics, 1(2), 88-92. https://doi.org/10.1016/j.fsigen.2007.01.018

674 Parson, W., Gusmão, L., Hares, D. R. R., Irwin, J. A. A., Mayr, W. R. R., Morling, N., Parsons, 675 T. J. J. (2014). DNA Commission of the International Society for Forensic Genetics: 676 Revised and extended guidelines for mitochondrial DNA typing. Forensic Science 677 International: Genetics, 13, 134-142. https://doi.org/10.1016/j.fsigen.2014.07.010 678 Parson, W., Strobl, C., Huber, G., Zimmermann, B., Gomes, S. M., Souto, L., Lagace, R. 679 (2013). Forensic Science International : Genetics Evaluation of next generation mtGenome 680 sequencing using the Ion Torrent Personal Genome Machine ( PGM ), 7, 543-549. $681 \quad$ https://doi.org/10.1016/j.fsigen.2013.06.003

682 Paus, R. (1998). Principles of hair cycle control. Journal of Dermatology, 25(12), 793-802.

683 https://doi.org/10.1111/j.1346-8138.1998.tb02507.x

684 Peck, M. A., Brandhagen, M. D., Marshall, C., Diegoli, T. M., Irwin, J. A., \& Sturk-Andreaggi, 685 K. (2016). Concordance and reproducibility of a next generation mtGenome sequencing 686 method for high-quality samples using the Illumina MiSeq. Forensic Science International: 687 Genetics, 24, 103-111. https://doi.org/10.1016/j.fsigen.2016.06.003 
688 Picard, M., Wallace, D. C., \& Burelle, Y. (2016). Mitochondrion The rise of mitochondria in 689 medicine. MITOCH, 30, 105-116. https://doi.org/10.1016/j.mito.2016.07.003

690 Piccinini, A., Coco, S., Parson, W., Cattaneo, C., Gaudio, D., Barbazza, R., \& Galassi, A. (2010).

691 World war one Italian and Austrian soldier identification project: DNA results of the first 692 case. Forensic Science International: Genetics, 4(5), 329-333.

693 https://doi.org/10.1016/j.fsigen.2009.10.005

694 Poletto, M. M., Malaghini, M., Silva, J. S., Bicalho, M. G., \& Braun-Prado, K. (2019).

695 Mitochondrial DNA control region diversity in a population from Parana state — increasing 696 the Brazilian forensic database. International Journal of Legal Medicine, 133(2), 347-351. 697 https://doi.org/10.1007/s00414-018-1886-5

698 Prinz, M., Carracedo, A., Mayr, W. R., Morling, N., Parsons, T. J., Sajantila, A., Schneider, P. 699 M. (2007). DNA Commission of the International Society for Forensic Genetics (ISFG):

700 Recommendations regarding the role of forensic genetics for disaster victim identification 701 (DVI). Forensic Science International: Genetics, 1(1), 3-12.

$702 \quad$ https://doi.org/10.1016/j.fsigen.2006.10.003

703 Pukk, L., Ahmad, F., Hasan, S., Kisand, V., Gross, R., \& Vasemägi, A. (2015). Less is more:

704 Extreme genome complexity reduction with ddRAD using Ion Torrent semiconductor 705 technology. Molecular Ecology Resources, 15(5), 1145-1152. https://doi.org/10.1111/1755$706 \quad 0998.12392$

707 708

709

710

Ríos, L., Ovejero, J.I., Prieto J.P. (2010). Identification process in mass graves from the Spanish Civil War I. Forensic Science International, 199(1-3). https://doi.org/10.1016/j.forsciint.2010.02.023

Röck, A. W., Dür, A., Van Oven, M., \& Parson, W. (2013). Concept for estimating 
711

712

713 Rogers, G. E. (2004). Hair follicle differentiation and regulation. International Journal of

714 Developmental Biology, 48(2-3), 163-170. https://doi.org/10.1387/ijdb.15272381

715 Rosa, A., Brehm, A., Kivisild, T., Metspalu, E., \& Villems, R. (2004). MtDNA profile of West

716 Africa Guineans: Towards a better understanding of the Senegambia region. Annals of

717

718

719

720

721

722

723

724

725

726

727

728

729

730

731

732

733

mitochondrial DNA haplogroups using a maximum likelihood approach (EMMA). Forensic

Science International: Genetics, 7(6), 601-609. https://doi.org/10.1016/j.fsigen.2013.07.005

Human Genetics, 68(4), 340-352. https://doi.org/10.1046/j.1529-8817.2004.00100.x

Rothberg, J. M., Hinz, W., Rearick, T. M., Schultz, J., Mileski, W., Davey, M., Bustillo, J.

(2011). An integrated semiconductor device enabling non-optical genome sequencing.

Nature, 475(7356), 348-352. https://doi.org/10.1038/nature10242

Ruiz-Pesini, E., Lott, M. T., Procaccio, V., Poole, J. C., Brandon, M. C., Mishmar, D., Wallace, D. C. (2007). An enhanced MITOMAP with a global mtDNA mutational phylogeny. Nucleic Acids Research, 35(SUPPL. 1), 823-828. https://doi.org/10.1093/nar/gk1927

Sanger, F., Nicklen, S., \& Coulson, A. R. (1977). DNA sequencing with chain-terminating inhibitors. Proceedings of the National Academy of Sciences, 74(12), 5463-5467. https://doi.org/10.1073/pnas.74.12.5463

Scally, A. (2016). The mutation rate in human evolution and demographic inference. Current Opinion in Genetics and Development, 41, 36-43. https://doi.org/10.1016/j.gde.2016.07.008

Shendure, J., Porreca, G. J., Reppas, N. B., Lin, X., McCutcheon, J. P., Rosenbaum, A. M., Church, G. M. (2005). Molecular biology: Accurate multiplex polony sequencing of an evolved bacterial genome. Science, 309(5741), 1728-1732.

https://doi.org/10.1126/science.1117389

Shitara, H., Hayashi, J. I., Takahama, S., Kaneda, H., \& Yonekawa, H. (1998). Maternal

Peer] reviewing PDF | (2019:01:34345:2:2:NEW 7 Jun 2019) 
734

735

736

737

738

739

740

741

742

743

744

745

746

747

748

749

750

751

752

753

754

755

756

inheritance of mouse mtDNA in interspecific hybrids: Segregation of the leaked paternal mtDNA followed by the prevention of subsequent paternal leakage. Genetics, 148(2), 851857. https://doi.org/10.1093/nar/17.18.7325

Shitara, H., Kaneda, H., Sato, A., Inoue, K., Ogura, A., Yonekawa, H., \& Hayashi, J. I. (2000). Selective and continuous elimination of mitochondria microinjected into mouse eggs from spermatids, but not from liver cells, occurs throughout emborogenesis. Genetics, 156(3), 1277-1284. https://doi.org/10.1073/pnas.1303231110

Shokolenko, I. N. (2014). Aging: A mitochondrial DNA perspective, critical analysis and an update. World Journal of Experimental Medicine, 4(4), 46. https://doi.org/10.5493/wjem.v4.i4.46

Sigurðardóttir, S., Helgason, A., Gulcher, J. R., Stefansson, K., \& Donnelly, P. (2000). The Mutation Rate in the Human mtDNA Control Region. American Journal of Human Genetics, 66, 1599-1609. https://doi.org/Doi 10.1086/302902

Stewart, J. E., Fisher, C. L., Aagaard, P. J., Wilson, M. R., Isenberg, A. R., Polanskey, D., Budowle, B. (2001). Length variation in HV2 of the human mitochondrial DNA control region. Journal of Forensic Sciences, 46(4), 862-870. https://doi.org/10.1520/JFS15059J

Stoneking, M., Hedgecock, D., Higuchi, R. G., Vigilant, L., \& Erlich, H. A. (1991). Population variation of human mtDNA control region sequences detected by enzymatic amplification and sequence-specific oligonucleotide probes. American Journal of Human Genetics, 48(2), $370-382$.

Strobl, C., Eduardoff, M., Bus, M. M., Allen, M., \& Parson, W. (2018). Evaluation of the precision ID whole MtDNA genome panel for forensic analyses. Forensic Science International: Genetics, 35(March), 21-25. https://doi.org/10.1016/j.fsigen.2018.03.013 
757 Sullivan, K. M., Hopgood, R., \& Gill, P. (1992). Identification of human remains by

758 amplification and automated sequencing of mitochondrial DNA. International Journal of

759 Legal Medicine, 105(2), 83-86. https://doi.org/10.1007/BF02340829

760 Taanman, J.-W. (1999). The mitochondrial genome: structure, transcription, translation and

761 replication. Biochimica et Biophysica Acta (BBA) - Bioenergetics, 1410(2), 103-123.

$762 \quad$ https://doi.org/10.1016/S0005-2728(98)00161-3

763 Templeton, J. E. L., Brotherton, P. M., Llamas, B., Soubrier, J., Haak, W., Cooper, A., \& Austin,

764 J. J. (2013). DNA capture and next-generation sequencing can recover whole mitochondrial

765 genomes from highly degraded samples for human identification. Investigative Genetics,

766 4(1), 1-13. https://doi.org/10.1186/2041-2223-4-26

767 Torroni, A., Huoponen, K., Francalacci, P., Petrozzi, M., Morelli, L., Scozzari, R., Wallace, D.

768 C. (1996). Classification of european mtDNAs from an analysis of three European 769 populations. Genetics, 144(4), 1835-1850.

770 Tully, G., Bär, W., Brinkmann, B., Carracedo, A., Gill, P., Morling, N., Schneider, P. (2001).

771 Considerations by the European DNA profiling (EDNAP) group on the working practices,

772 nomenclature and interpretation of mitochondrial DNA profiles. Forensic Science

773 International, 124(1), 83-91. https://doi.org/10.1016/S0379-0738(01)00573-4

774 Turchi, C., Stanciu, F., Paselli, G., Buscemi, L., Parson, W., \& Tagliabracci, A. (2016). The

775 mitochondrial DNA makeup of Romanians: A forensic mtDNA control region database and

776 phylogenetic characterization. Forensic Science International: Genetics, 24, 136-142.

777 https://doi.org/10.1016/j.fsigen.2016.06.013

778 van Oven, M. (2015). PhyloTree Build 17: Growing the human mitochondrial DNA tree.

779 Forensic Science International: Genetics Supplement Series, 5, e392-e394. 
780

781

782

783

784

785

786

787

788

789

790

791

792

793

794

795

796

797

798

799

800

801

802

https://doi.org/10.1016/j.fsigss.2015.09.155

van Oven, M., \& Kayser, M. (2008). Updated comprehensive phylogenetic tree of global human mitochondrial DNA variation. Human Mutation, 30(September), 386-394. https://doi.org/10.1002/humu.20921

Wallace, D. C. (2007). Why Do We Still Have a Maternally Inherited Mitochondrial DNA? Insights from Evolutionary Medicine. Annual Review of Biochemistry, 76(1), 781-821. https://doi.org/10.1146/annurev.biochem.76.081205.150955

Wallace, H. M., Jackson, A. R., Gruber, J., \& Thibedeau, A. D. (2014). Forensic DNA databases-Ethical and legal standards: A global review. Egyptian Journal of Forensic Sciences, 4(3), 57-63. https://doi.org/10.1016/j.ejfs.2014.04.002

Wei, W., Keogh, M. J., Wilson, I., Coxhead, J., Ryan, S., Rollinson, S., Chinnery, P. F. (2017). Mitochondrial DNA point mutations and relative copy number in 1363 disease and control human brains. Acta Neuropathologica Communications, 5(1), 13. https://doi.org/10.1186/s40478-016-0404-6

Wilson, M. R., Polanskey, D., Replogle, J., DiZinno, J. A., \& Budowle, B. (1997). A family exhibiting heteroplasmy in the human mitochondrial DNA control region reveals both somatic mosaicism and pronounced segregation of mitotypes. Human Genetics, 100(2), 167-171. https://doi.org/10.1007/s004390050485

Woerner, A. E., Ambers, A., Wendt, F. R., King, J. L., Moura-Neto, R. S., Silva, R., \& Budowle, B. (2018). Evaluation of the precision ID mtDNA whole genome panel on two massively parallel sequencing systems. Forensic Science International: Genetics, 36(March), 213224. https://doi.org/10.1016/j.fsigen.2018.07.015

Yasmin, M., Rakha, A., Noreen, S., \& Salahuddin, Z. (2017). Mitochondrial control region 
803 diversity in Sindhi ethnic group of Pakistan. Legal Medicine, 26, 11-13.

804 https://doi.org/10.1016/j.legalmed.2017.02.001

805 Young, B., King, J. L., Budowle, B., \& Armogida, L. (2017). A technique for setting analytical

806 thresholds in massively parallel sequencing-based forensic DNA analysis. PLoS ONE,

807 12(5), 1-15. https://doi.org/10.1371/journal.pone.0178005

808 


\section{Legends to figures and tables}

810

811 Figure 1 - The human mitochondrial DNA genome with genes and control regions labeled.

812 Adapted from Picard et al., 2016 (Picard, Wallace, \& Burelle, 2016)

813

814 Figure 2 - Representation of the geographical origin of the main mtDNA haplogroups, based on 815 Lott et al., 2014 (Lott et al., 2014)

816

817 Table 1 - Guidelines of the DNA Commission of the International Society of Forensic Genetics, 8182014.

819

820 Table 2 - Selected published cases of human identification with mtDNA 
Figure 1

The human mitochondrial DNA genome with genes and control regions labeled. Adapted from Picard et al., 2016 (Picard, Wallace, \& Burelle, 2016)

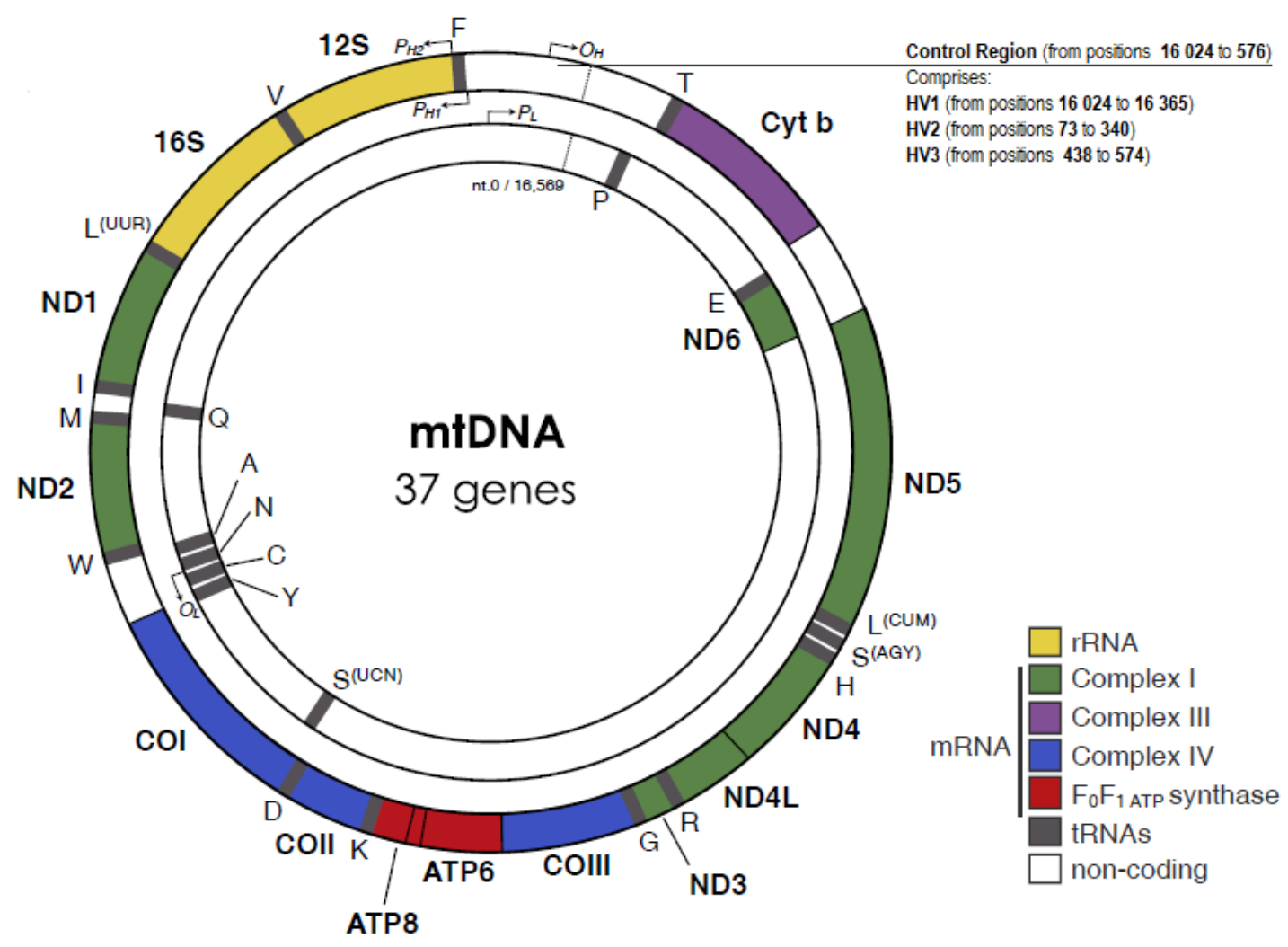


Figure 2

Representation of the geographical origin of the main mtDNA haplogroups, based on Lott et al., 2014 (Lott et al., 2014)

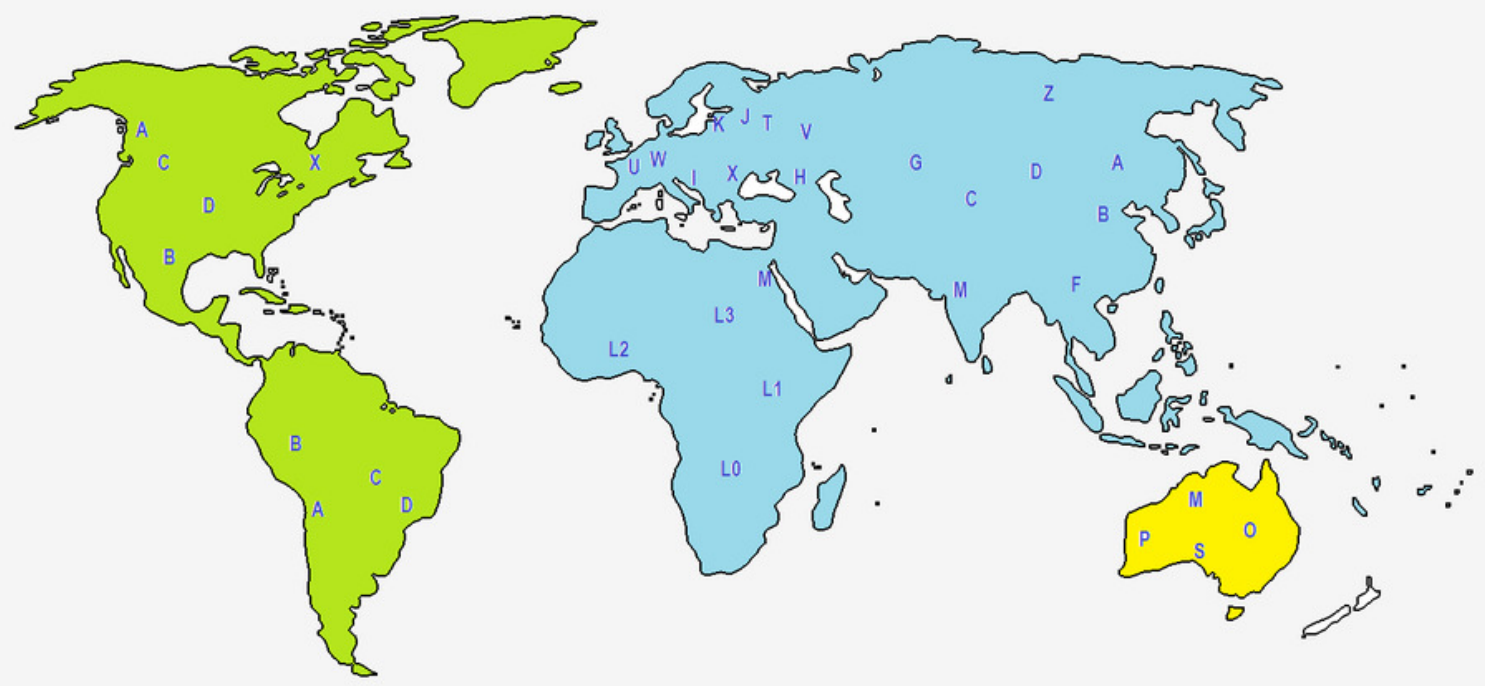




\section{Table $\mathbf{1}$ (on next page)}

Guidelines of the DNA Commission of the InternationalSociety of Forensic Genetics

Guidelines of the DNA Commission of the International Society of Forensic Genetics, 2014. 
1 Table 1 - Guidelines of the DNA Commission of the International Society of Forensic Genetics, 2014

\begin{tabular}{|c|c|c|}
\hline Addressement & Recommendation & Statement \\
\hline $\begin{array}{l}\text { General recommendations/ good laboratory } \\
\text { practice }\end{array}$ & $\begin{array}{l}\text { Recommendation } \\
\# 1 \\
\text { Recommendation } \\
\# 2 \\
\text { Recommendation } \\
\# 3 \\
\text { Recommendation } \\
\# 4 \\
\text { Recommendation } \\
\# 5\end{array}$ & $\begin{array}{l}\text { Good laboratory practice and specific protocols for work with mtDNA must be followed in accordance } \\
\text { with previous guidelines } \\
\text { Negative and positive controls as well as extraction reagent blanks must be carried through the entire } \\
\text { laboratory process } \\
\text { Reported consensus sequences must be based on redundant sequence information, using forward and } \\
\text { reverse sequencing reactions whenever practical } \\
\text { Manual transcription of data should be avoided and independent confirmation of consensus haplotypes } \\
\text { by two scientists must be performed } \\
\text { Laboratories using mtDNA typing in forensic casework shall participate regularly in suitable proficiency } \\
\text { testing programs }\end{array}$ \\
\hline $\begin{array}{l}\text { Targeted region, amplification and } \\
\text { sequencing ranges }\end{array}$ & $\begin{array}{l}\text { Recommendation } \\
\# 6\end{array}$ & $\begin{array}{l}\text { In population genetic studies for forensic databasing purposes, the entire mitochondrial DNA control } \\
\text { region should be sequenced. }\end{array}$ \\
\hline Reference sequence & $\begin{array}{l}\text { Recommendation } \\
\# 7\end{array}$ & $\begin{array}{l}\text { MtDNA sequences should be aligned and reported relative to the revised Cambridge Reference } \\
\text { Sequence (rCRS, NC001807), and should include the interpretation range (excluding primer sequence } \\
\text { information) }\end{array}$ \\
\hline Alignment and notation & $\begin{array}{l}\text { Recommendation } \\
\# 9\end{array}$ & $\begin{array}{l}\text { IUPAC conventions using capital letters shall be used to describe differences to the rCRS and (point } \\
\text { heteroplasmic) mixtures. Lower case letters should be used to indicate mixtures between deleted and } \\
\text { non-deleted (inserted and non-inserted) bases. N-designations should only be used when all four bases } \\
\text { are observed at a single position (or if no base call can be made at a given position). For the } \\
\text { representation of deletions, "DEL", "del" or "S" shall be used } \\
\text { The alignment and notation of mtDNA sequences should be performed in agreement with the } \\
\text { mitochondrial phylogeny (established patterns of mutations). Tools to assist with the notation of mtDNA } \\
\text { sequences are available at http:// empop.org/ }\end{array}$ \\
\hline Heteroplasmy & $\begin{array}{l}\text { Recommendation } \\
\# 11\end{array}$ & $\begin{array}{l}\text { In forensic casework, laboratories must establish their own interpretation and reporting guidelines for } \\
\text { observed length and point heteroplasmy. The evaluation of heteroplasmy depends on the limitations of } \\
\text { the technology and the quality of the sequencing reactions as well as the experience of the laboratory. } \\
\text { Differences in both PHP and LHP do not constitute evidence for excluding two otherwise identical } \\
\text { haplotypes as deriving from the same source or same maternal lineage } \\
\text { For population database samples, length heteroplasmy in homopolymeric sequence stretches should be } \\
\text { interpreted by calling the dominant variant, which can be determined by identifying the position with the } \\
\text { highest representation of a non-repetitive peak downstream of the affected stretch }\end{array}$ \\
\hline Haplogrouping of mtDNA sequences & $\begin{array}{l}\text { Recommendation } \\
\# 12\end{array}$ & $\begin{array}{l}\text { MtDNA population data should be subjected to analytical software tools that facilitate phylogenetic } \\
\text { checks for data quality control. A comprehensive suite of QC tools is provided by EMPOP }\end{array}$ \\
\hline Databases and database searches & $\begin{array}{l}\text { Recommendation } \\
\# 13 \\
\text { Recommendation } \\
\# 14 \\
\text { Recommendation } \\
\# 15 \\
\text { Recommendation } \\
\# 16\end{array}$ & $\begin{array}{l}\text { The entire database of available sequences should be searched with respect to the sequencing } \\
\text { (interpretation) range to avoid biased query results } \\
\text { Laboratories must be able to justify the choice of database(s) and statistical approach used in reporting } \\
\text { Laboratories must establish statistical guidelines for use in reporting an mtDNA match between two } \\
\text { samples } \\
\text { Highly variable positions such as length variants in homopolymeric stretches should be disregarded from } \\
\text { searches for determining frequency estimates. Heteroplasmic calls should be queried in a manner that }\end{array}$ \\
\hline
\end{tabular}




\section{Table 2 (on next page)}

Selectedpublished cases of human identification with mtDNA.

Selected published cases of human identification with mtDNA. 
1 Table 2 - Selected published cases of human identification with mtDNA

\begin{tabular}{|c|c|c|c|c|c|}
\hline Reference/Year & $\begin{array}{l}\text { Studied } \\
\text { samples }\end{array}$ & $\begin{array}{l}\text { mtDNA } \\
\text { studied } \\
\text { regions }\end{array}$ & $\begin{array}{l}\text { Used } \\
\text { methodologies }\end{array}$ & Reference samples & Results \\
\hline $\begin{array}{l}\text { Stoneking M, Hedgecock D, Higuchi } \\
\text { RG, Vigilant L, Erlich HA. } \\
\text { Population variation of human } \\
\text { mtDNA control region sequences } \\
\text { detected by enzymatic amplification } \\
\text { and sequence-specific } \\
\text { oligonucleotide probes. Am J Hum } \\
\text { Genet. 1991;48(2):370-82. }\end{array}$ & $\begin{array}{l}\text { Skeletal } \\
\text { remains of a } \\
\text { human child, } \\
\text { found in } 1986\end{array}$ & HVI, HVII & $\begin{array}{l}\text { PCR for } \\
\text { amplification } \\
\text { Hybridization with } \\
\text { oligonucleotide } \\
\text { probes for } \\
\text { sequence } \\
\text { determination }\end{array}$ & $\begin{array}{l}\text { Parents of a 3-year- } \\
\text { old child disappeared } \\
\text { from home in } 1984\end{array}$ & $\begin{array}{l}\text { Identical mtDNA } \\
\text { sequence in skeletal } \\
\text { remains and sample of } \\
\text { the 3-year-old child } \\
\text { mother } \\
\text { Positive ID }\end{array}$ \\
\hline $\begin{array}{l}\text { Sullivan KM, Hopgood R, Gill P. } \\
\text { Identification of human remains by } \\
\text { amplification and automated } \\
\text { sequencing of mitochondrial DNA. } \\
\text { Int J Legal Med. 1992;105(2):83-6. }\end{array}$ & $\begin{array}{l}\text { Body of a } \\
\text { female, in an } \\
\text { advanced } \\
\text { state of } \\
\text { decomposition } \\
\text { discovered in } \\
1990 \\
\end{array}$ & HVI, HVII & $\begin{array}{l}\text { PCR for } \\
\text { amplification } \\
\text { Sanger } \\
\text { sequencing }\end{array}$ & $\begin{array}{l}\text { Blood sample from a } \\
\text { sister of a deceased } \\
\text { female at the same } \\
\text { region }\end{array}$ & $\begin{array}{l}\text { No differences were } \\
\text { observed between the } \\
\text { corpse and blood from } \\
\text { the putative sister } \\
\text { Positive ID }\end{array}$ \\
\hline $\begin{array}{l}\text { Gill P, Ivanov PL, Kimpton C, Piercy } \\
\text { R, Benson N, Tully G, et al. } \\
\text { Identification of the remains of the } \\
\text { Romanov family by DNA analysis. } \\
\text { Nat Genet. } 1994 ; 6(2): 130-5 \text {. }\end{array}$ & $\begin{array}{l}\text { Nine skeletons } \\
\text { found in a } \\
\text { grave in } \\
\text { Ekaterinburg, } \\
\text { Russia, } 1991\end{array}$ & $\mathrm{HVI}, \mathrm{HVII}$ & $\begin{array}{l}\text { PCR for } \\
\text { amplification } \\
\text { Sanger } \\
\text { sequencing }\end{array}$ & $\begin{array}{l}\text { Blood sample from } \\
\text { Gt. Gt. Grandson of } \\
\text { Louise of Hesse- } \\
\text { Cassel and from Gt. } \\
\text { Gt. Gt. } \\
\text { Granddaughter of } \\
\text { Louise of Hesse- } \\
\text { Cassel }\end{array}$ & $\begin{array}{l}\text { Exact sequence between } \\
\text { putative Tsarina } \\
\text { Alexandra and putative } \\
\text { three children. } \\
\text { Exact mtDNA results } \\
\text { between putative Tsar } \\
\text { Nicholas II and two living } \\
\text { maternal relatives of the } \\
\text { Tsar }\end{array}$ \\
\hline $\begin{array}{l}\text { Ivanov PL, Wadhams MJ, Roby RK, } \\
\text { Holland MM WV\& PT. Mitochondrial } \\
\text { DNA sequence heteroplasmy in the } \\
\text { Grand Duke of Russia Georgij } \\
\text { Romanov establishes the } \\
\text { authenticity of the remains of Tsar } \\
\text { Nicholas II. Nat Genet. } \\
\text { 1996;(12):417-20. }\end{array}$ & $\begin{array}{l}\text { Skeleton of } \\
\text { putative Tsar } \\
\text { Nicholas II }\end{array}$ & $\mathrm{HVI}, \mathrm{HVII}$ & $\begin{array}{l}\text { PCR for } \\
\text { amplification } \\
\text { Sanger } \\
\text { sequencing }\end{array}$ & $\begin{array}{l}\text { Skeleton of Grand } \\
\text { Duke of Russia } \\
\text { Georgij Romanov } \\
\text { (Tsar's brother) } \\
\text { Blood sample from } \\
\text { Countess Xenia } \\
\text { Cheremeteff-Sfiri } \\
\text { (maternal Tsar's } \\
\text { relative) } \\
\end{array}$ & $\begin{array}{l}\text { Establishment of the } \\
\text { authenticity of the } \\
\text { remains of Tsar Nicholas } \\
\text { II }\end{array}$ \\
\hline $\begin{array}{l}\text { Deng YJ, Li YZ, Yu XG, Li L, Wu } \\
\text { DY, Zhou J, et al. Preliminary DNA } \\
\text { identification for the tsunami victims } \\
\text { in Thailand. Genomics, Proteomics } \\
\text { Bioinforma. 2005;3(3):143-57. }\end{array}$ & $\begin{array}{l}258 \text { tooth } \\
\text { samples from } \\
\text { killed people at } \\
\text { the } 2004 \\
\text { Southeast } \\
\text { Asia Thailand }\end{array}$ & HVI, HVII & $\begin{array}{l}\text { PCR for } \\
\text { amplification } \\
\text { Sanger } \\
\text { sequencing }\end{array}$ & $\begin{array}{l}200 \text { relatives of the } \\
\text { tsunami victims }\end{array}$ & $\begin{array}{l}200 \text { tsunami victims have } \\
\text { been identified, including } \\
\text { both Thai nationals and } \\
\text { foreign tourists from } \\
\text { several nations }\end{array}$ \\
\hline
\end{tabular}




\begin{tabular}{|c|c|c|c|c|c|}
\hline & Tsunami & & & & \\
\hline $\begin{array}{l}\text { Ríos L, García-Rubio A, Martínez B, } \\
\text { Alonso A, Puente J. Identification } \\
\text { process in mass graves from the } \\
\text { Spanish Civil War II. Forensic Sci } \\
\text { Int. 2010;219(1-3). }\end{array}$ & $\begin{array}{l}\text { Skeletal } \\
\text { remains } \\
\text { exhumed from } \\
\text { a mass grave } \\
\text { from the } \\
\text { Spanish Civil } \\
\text { War (1936- } \\
\text { 1939) }\end{array}$ & HVI, HVII & $\begin{array}{l}\text { PCR for } \\
\text { amplification } \\
\text { Sanger } \\
\text { sequencing }\end{array}$ & $\begin{array}{l}\text { Sister of the youngest } \\
\text { person presumptively } \\
\text { known to be buried in } \\
\text { the grave }\end{array}$ & $\begin{array}{l}\text { Match between mtDNA } \\
\text { profiles of the biologically } \\
\text { youngest skeleton and } \\
\text { the sister of the youngest } \\
\text { person presumptively } \\
\text { known to be buried in the } \\
\text { grave }\end{array}$ \\
\hline $\begin{array}{l}\text { Piccinini A, Coco S, Parson W, } \\
\text { Cattaneo C, Gaudio D, Barbazza R, } \\
\text { et al. World war one Italian and } \\
\text { Austrian soldier identification } \\
\text { project: DNA results of the first } \\
\text { case. Forensic Sci Int Genet. } \\
\text { 2010;4(5):329-33. }\end{array}$ & $\begin{array}{l}\text { Remains of } \\
\text { missing } \\
\text { soldiers } \\
\text { occasionally } \\
\text { found during } \\
\text { excavations }\end{array}$ & HVI, HVII & $\begin{array}{l}\text { PCR for } \\
\text { amplification } \\
\text { Sanger } \\
\text { sequencing }\end{array}$ & $\begin{array}{l}\text { Offspring of the italian } \\
\text { soldier Libero Zugni } \\
\text { Tauro }\end{array}$ & $\begin{array}{l}\text { Both mtDNA and Y-STR } \\
\text { data showed clear } \\
\text { exclusion scenarios } \\
\text { between the human } \\
\text { remains and the } \\
\text { reference samples }\end{array}$ \\
\hline $\begin{array}{l}\text { King TE, Fortes GG, Balaresque P, } \\
\text { Thomas MG, Balding D, Delser PM, } \\
\text { et al. Identification of the remains of } \\
\text { King Richard III. Nat Commun. } \\
2014 ; 5: 1-8 \text {. }\end{array}$ & $\begin{array}{l}\text { Skeleton } \\
\text { excavated at } \\
\text { the presumed } \\
\text { site of the } \\
\text { Grey Friars } \\
\text { friary in } \\
\text { Leicester, } \\
2012 \\
\end{array}$ & $\begin{array}{l}\text { Whole } \\
\text { mitochondrial } \\
\text { genome }\end{array}$ & $\begin{array}{l}\text { PCR for } \\
\text { amplification } \\
\text { Massive parallel } \\
\text { sequencing }\end{array}$ & $\begin{array}{l}\text { Saliva samples of the } \\
\text { modern relatives of } \\
\text { Richard III }\end{array}$ & $\begin{array}{l}\text { Positive mtDNA match } \\
\text { between the only known } \\
\text { female-line of Richard III } \\
\text { and studied modern } \\
\text { relatives of Richard III }\end{array}$ \\
\hline $\begin{array}{l}\text { Ossowski A, Diepenbroek M, } \\
\text { Kupiec T, Bykowska-Witowska M, } \\
\text { Zielińska G, Dembińska T, et al. } \\
\text { Genetic Identification of Communist } \\
\text { Crimes' Victims (1944-1956) Based } \\
\text { on the Analysis of One of Many } \\
\text { Mass Graves Discovered on the } \\
\text { Powazki Military Cemetery in } \\
\text { Warsaw, Poland. J Forensic Sci. } \\
\text { 2016;61(6):1450-5. }\end{array}$ & $\begin{array}{l}\text { Remains of } \\
\text { eight people } \\
\text { buried in one } \\
\text { of many mass } \\
\text { graves, which } \\
\text { were found at } \\
\text { the cemetery } \\
\text { Powazzki } \\
\text { Military in } \\
\text { Warsaw, } \\
\text { Poland }\end{array}$ & HVI, HVII & $\begin{array}{l}\text { PCR for } \\
\text { amplification } \\
\text { Sanger } \\
\text { sequencing }\end{array}$ & $\begin{array}{l}\text { Reference material } \\
\text { was collected from } \\
\text { the closest living } \\
\text { relatives of } \\
\text { Communist Crimes' } \\
\text { Victims (1944-1956) }\end{array}$ & $\begin{array}{l}\text { Positive mtDNA match } \\
\text { between } 6 \text { putative } \\
\text { victims and } 6 \text { living } \\
\text { relatives }\end{array}$ \\
\hline $\begin{array}{l}\text { Ambers AD, Churchill JD, King JL, } \\
\text { Stoljarova M, Gill-King H, Assidi M, } \\
\text { et al. More comprehensive forensic } \\
\text { genetic marker analyses for } \\
\text { accurate human remains } \\
\text { identification using massively } \\
\text { parallel DNA sequencing. BMC } \\
\text { Genomics. 2016;17(Suppl 9). }\end{array}$ & $\begin{array}{l}\text { Human } \\
\text { skeletal } \\
\text { remains with } \\
140 \text {-year-old } \\
\text { discovered at } \\
\text { a historical site } \\
\text { in Deadwood, } \\
\text { South Dakota, } \\
\text { United States }\end{array}$ & $\begin{array}{l}\text { HVI, HVII } \\
\text { and ten } \\
\text { fragments of } \\
\text { mtDNA } \\
\text { coding } \\
\text { region }\end{array}$ & $\begin{array}{l}\text { PCR for } \\
\text { amplification } \\
\text { Massive parallel } \\
\text { sequencing }\end{array}$ & Not used & $\begin{array}{l}\text { Results were consistent } \\
\text { with previous } \\
\text { anthropological report } \\
\text { that points to a male of } \\
\text { European ancestry }\end{array}$ \\
\hline
\end{tabular}


